Masyarakat Berdaya dan Inovasi

2 (2), 2021, 135 - 143

Available online: https://mayadani.org/index.php/MAYADANI

\title{
Peningkatan Kegiatan Pembelajaran melalui Pengembangan Kompetensi Guru: Pendampingan Kegiatan Pembelajaran Pendidikan Agama Islam di MTs Alharanain Lappara Kec.Tombolopao Kab.Gowa
}

\author{
Abd. Rahim Razaq ${ }^{1}$, Umiarso ${ }^{2 *}$ \\ ${ }^{12}$ Universitas Muhammadiyah Makassar, Jl. Sultan Alauddin No.259, Gn. Sari, Kec. Rappocini, Kota \\ Makassar, Sulawesi Selatan 90221 \\ ${ }^{12}$ Universitas Muhammadiyah Malang, J1. Raya Tlogomas No.246 Malang, Jawa Timur \\ Email: umiarso@umm.ac.id No Hp.082330647295
}

Received: 31 September 2021; Revision: 15 Oktober 2021; Accepted: 04 November 2021

\begin{abstract}
Abstrak
Pengabdian ini ditujukan memberikan pendampingan berupa pelatihan melalui sharing keilmuan dan pengalaman dengan guru bidang studi Pendidikan Agama Islam di MTs Alharanain Lappara Kec.Tombolopao Kab.Gowa. Melalui pendampingan tersebut ada proses pembentukan pengatahuan berbasis wawasan perencanaan pembelajaran yang dilakukan guru bidang studi Pendidikan Agama Islam. Kegiatan pendampingan ini dipilih sebagai solusi terhadap problematika pembelajaran Pendidikan Agama Islam di MTs tersebut. Bentuk kegiatan berupa pelatihan penyusunan perencanaan pembelajaran yang dikemas melalui tutorial dan eksperiental learning; dan untuk evaluasinya dilakukan secara monitoring dan pendampingan berupa pelatihan melalui sharing keilmuan dan pengalaman. Kegiatan pengabdian ini berdampak pada peningkatan performa guru Pendidikan Agama Islam yang dibuktikan melalui penilaian berkas-berkas pembelajaran yang digunakan mereka. Karenanya, kepala sekolah setiap saat secara berkala mengadakan upaya yang sama berupa kegiatan pelatihan metodologi pembelajaran pada semua bidang studi.
\end{abstract}

Kata kunci: Guru, Pembelajaran, Pendidikan Agama Islam.

\begin{abstract}
This This service is intended to assist in the form of training through sharing knowledge and experience with teachers in the field of Islamic Religious Education at MTs Alharanain Lappara Kec.Tombolopao Kab.Gowa. Through this assistance, there is a process of forming knowledge based on learning planning insights carried out by teachers in the field of Islamic Religious Education. This mentoring activity was chosen as a solution to the problems of learning Islamic Religious Education in the MTs. The form of activity is in the form of training in the preparation of learning plans that are packaged through tutorials and experiential learning, and the evaluation is carried out by monitoring and mentoring in the form of training through sharing knowledge and experience. This service activity has an impact on improving the performance of Islamic Religious Education teachers as evidenced by the assessment of the learning files they use. Therefore, the principal at all times periodically conducts the same effort in the form of training on learning methodologies in all fields of study.
\end{abstract}

Keywords: Teachers, Learning, Islamic Religious Education.

How to Cite: Razaq, A., \& Umiarso, U. (2021). Peningkatan Kegiatan Pembelajaran melalui Pengembangan Kompetensi Guru: Pendampingan Kegiatan Pembelajaran Pendidikan Agama Islam di SMK Muhammadiyah Majenang. Masyarakat Berdaya dan Inovasi, 2(2). doi:https://doi.org/10.33292/mayadani.v2i2.72 


\section{PENDAHULUAN}

Pengabdian ini ditujukan memberikan pendampingan berupa pelatihan melalui sharing keilmuan dan pengalaman dengan guru bidang studi Pendidikan Agama Islam di MTs Alharanain Lappara Kec.Tombolopao Kab.Gowa. Orientasinya, ia nantinya mampu menguasai metodologi pembelajaran dengan baik. Kegiatan pendampingan diteruskan dengan program pelatihan terhadap guru Pendidikan Agama Islam dalam satu kegiatan penyusunan perangkat pembelajaran. Melalui dua kegiatan ini diharapkan mampu meningkatkan dan mengembangkan kemampuan guru dalam metodologi proses belajar mengajar. Untuk meningkatkan kualitas kegiatan pembelajaran Pendidikan Agama Islam yang dilakukan oleh guru, maka guru perlu memiliki dan menguasai perencanaan kegiatan tersebut. Artinya, melaksanakan kegiatan pembelajaran yang direncanakan dan melakukan penilaian terhadap hasil dari proses tersebut. Pengabdian ini merujuk dari hasil pengabdian yang dilakukan oleh Usman Sutisna dengan judul Pengembangan kompetensi profesional guru PAI melalui pemanfaatan teknologi informasi ( et al., 2020, p. 43), dimana hasil yang didapatkan dari pengabdian tersebut adalah penggunaa teknologi informasi dapat dimanfaatkan dengan baik oleh guru PAI, akan tetapi kelemahan dalam pengabdian ini adalah kurangnya implementatif yang bersifat Eksperiental Learning, dimana kegiatan ini dilakukan dengan memberikan pengalaman langsung bagi GPAI yang terkait kegiatan penyusunan perencanaan pembelajaran. Seperti yang diungkapkan Uno bahwa guru harus menguasai beberapa hal diantaranya adalah merencanakan sistem pembelajaran, melaksanakan sistem pembelajaran, mengevaluasi sistem pembelajaran, dan mengembangkan sistem pembelajaran (Uno, 2008, p. 19). Pada konteks inilah Usman menyatakan bahwa dari aspek yang menggambarkan kualifikasi atau kemampuan seseorang guru baik yang kualitatif maupun kuantitatif disebut sebagai kompetensi guru (Usman, 2005, p. 14).

Kompetensi guru dalam merencanakan proses pembelajaran merupakan faktor utama dalam mencapai tujuan pengajaran secara spesifik maupun secara makro. Dimensi ini disadari oleh guru Pendidikan Agama Islam -selanjutnya ditulis GPAI- MTs Alharanain Lappara Kec.Tombolopao Kab.Gowa dan dinyaakan sebagai keterampilan yang erat kaitannya dengan tugas dan tanggung jawab guru sebagai pengajar yang mendidik. Artinya, kompetensi ini dalam hal pengelolaan pembelajaran sangat urgen untuk menentukan ketercapaian tujuan pendidikan. Dalam konteks ini, GPAI sebagai learning manager hendaknya mampu mengelola kelas sebagai lingkungan belajar serta dibentuk menjadi bagian dari lingkungan sekolah yang perlu diorganisasi (Usman, 2005, p. 10), Oleh sebab itu, sebagai pengajar, GPAI di MTs Alharanain Lappara Kec.Tombolopao Kab.Gowa perlu memiliki perencanaan (planning) pembelajaran yang matang. Perencanaan pembelajaran tersebut erat kaitannya dengan berbagai unsur seperti tujuan pembelajaran, materi pembelajaran, proses pembelajaran, metode mengajar, dan evaluasi. Unsur-unsur tersebut merupakan bagian integral dari keseluruhan tanggung jawab GPAI dalam proses pembelajaran. Wajar jika ada kalangan yang menyatakan, penyelenggaraan dan keberhasilan proses pendidikan pada semua jenjang dan semua satuan pendididikan juga ditentukan oleh faktor guru (Hamalik, 2009, p. V). Oleh karena itu, GPAI di MTs Alharanain Lappara Kec.Tombolopao Kab.Gowa 
diharapkan -atau bisa dikatakan seharusnya- memiliki kompetensi yang diperlukan untuk melaksanakan tugas dan fungsinya secara efektif dan efisien.

Secara spesifik GPAI di MTs Alharanain Lappara Kec.Tombolopao Kab.Gowa mempunyai nilai lebih dibandingkan dengan guru lainnya. Ia disamping melaksanakan tugas keagamaan, juga melaksanakan tugas pendidikan dan pembinaan bagi peserta didik. Bahkan ia membantu pembentukan kepribadian, pembinaan akhlak disamping menumbuhkan dan mengembangkan keimanan dan ketaqwaan para siswa. Apalagi PAI merupakan upaya yang mendidikkan agama Islam atau ajaran Islam dan nilai-nilainya agar menjadi way of life (pandangan dan sikap hidup) seseorang (Muhaimin, 2006, p. 5)(Muhaimin, 2005, p. 7). Dalam pembelajarannya pun harus tetap konsisten pada tujuannya yaitu untuk membentuk perilaku dan kepribadian individu sesuai dengan prinsip-prinsip dan konsep Islam dalam mewujudkan nilai-nilai moral dan agama sebagai landasan pencapaian tujuan pendidikan nasional (Mulyasa, 2004, p. 162). Dengan tugas yang cukup berat tersebut, GPAI dituntut untuk memiliki keterampilan profesional dalam menjalankan tugas pembelajaran.

Memang pembalajaran Pendidikan Agama Islam di MTs Alharanain Lappara Kec.Tombolopao Kab.Gowa kondusif dalam kerangka pembelajaran peserta didik aktif. Artinya, dalam kegiatan pembelajaran tersebut peserta didik dapat mengaktualisasikan dirinya sebagai subjek didik. Karenanya, ia dalam pengalaman belajarnya banyak mendapatkan pengetahuan dan nilai etika. Kegiatan pembelajarannya telah bisa mempoles dan mewarnai sikap peserta didik pada tataran psikomotor maupun kognitifnya. Hal ini diindikasikan dengan adanya relasi yang kuat antar peserta didik dengan peserta didik sendiri; atau antara GPAI dengan peserta didik. Dari aspek kompetensi GPAI sendiri, pembelajaran Pendidikan Agama Islam sendiri berlangsung sangat efektif dan efisien. GPAI banyak memberikan ruang dan peluang pada peserta didik untuk beraktivitas, berimprovisasi, dan berinovasi pada saat pembelajaran berlangsung. Apalagi didukung oleh meliu yang sangat kondusif dan media pembelajaran yang cukup representatif menjadikan pola kegiatan pembelajaran mampu diparalelkan dengan perkembangan peserta didik. Namun, kesan monoton dalam proses pembelajaran masih mewarnai dan akhirnya memunculkan kesan mengulang-ulang tindakan mendidik dan mengajar pada diri GPAI. Penguasaan materi pembelajaran GPAI sangat mumpuni dan juga bisa melakukan transfer pengetahuan secara efektif. Karenanya, perlu ada ruang peningkatan kompetensi GPAI terutama di dalam melakukan (re)desain pembelajaran Pendidikan Agama Islam.

\section{METODE}

Berdasarkan pada deskripsi analisis situasi tersebut dapat diidentifikasi adanya problematika dalam merencanakan kegiatan pembelajaran Pendidikan Agama Islam yang dilakukan GPAI. Problematika ini sangat esensial pada proses pembelajaran, sebab perencanaan pembelajaran yang tidak sesuai berakibat pada ketidakmampuan, ketidakefektifan dan kekurangtepatan guna kegiatan pembelajaran. Bahkan problem ini berimplikasi - selain yang telah disebutkan- pada merosotnya mutu Pendidikan Agama Islam di sekolah tersebut atau juga sekolah tersebut semakin menurun dimensi 
perilaku dan moraltasnya. Atas dasar tersebut maka perlu adanya pendampingan berupa pelatihan yang dapat dilakukan melalui sharing keilmuan dan pengalaman dengan GPAI. Sehingga ada proses pembentukan pengatahuan berbasis wawasan perencanaan pembelajaran. Implikasinya, ia diharapkan mempunyai kemampuan menguasai (re)desain pembelajaran dengan baik. Keadaan ini dapat pula dimunculkan suatu pendampingan berupa pelatihan terhadap guru-guru di MTs Alharanain Lappara Kec.Tombolopao Kab.Gowa dalam satu kegiatan penyusunan perencanaan pembelajaran. Dua hal inilah yang akan dilakukan dalam pengabdian ini agar bisa meningkatkan dan mengembangkan kemampuan (re)desain pembelajaran GPAI.

1. Kerangka Pemecahan Masalah

Perencanaan pembelajaran Pendidikan Agama Islam yang tidak sesuai berakibat pada ketidakmampuan, ketidakefektifan dan kekurangtepatan guna kegiatan pembelajaran. Bahkan akan mendorong terjadinya gap antara "yang seharusnya" dengan "senyatanya"; antara das sollen dan das sein tujuan yang hendak dicapai PAI. Implikasinya, kinerja GPAI tidak muncul secara maksimal dan cenderung performance mereka monoton. Oleh karenanya, perlu ada kegiatan pendampingan berupa pelatihan melalui sharing keilmuan dan pengalaman dengan GPAI dalam satu kegiatan penyusunan perencanaan pembelajaran. Kegiatan pendampingan ini dipilih sebagai solusi terhadap problematika pembelajaran Pendidikan Agama Islam tersebut dengan berbagai pertimbangan, antara lain:

a. Melalui pendampingan berupa kegiatan pelatihan diharapkan GPAI dapat secara efektif menggunakan waktunya untuk belajar, berinovasi dan berimprovisasi dalam pembelajaran.

b. Melalui pendampingan berupa kegiatan pelatihan diharapkan ada transfer ilmu pengetahuan dan keterampilan terkait dengan kegiatan penyusunan perencanaan pembelajaran.

c. Melalui pendampingan, secara tidak langsung memberikan peluang bagi GPAI untuk memberdayakan diri mereka dalam meningkatkan dan mengembangkan potensinya, sehingga muara akhirnya ada peningkatan mutu pembelajaran Pendidikan Agama Islam.

Adapun alur pemecahan problematika pembelajaran Pendidikan Agama Islam yang ada di MTs Alharanain Lappara Kec.Tombolopao Kab.Gowa dapat digambarkan dalam pendekatan sistem sebagaimana yang tergambar berikut ini: 


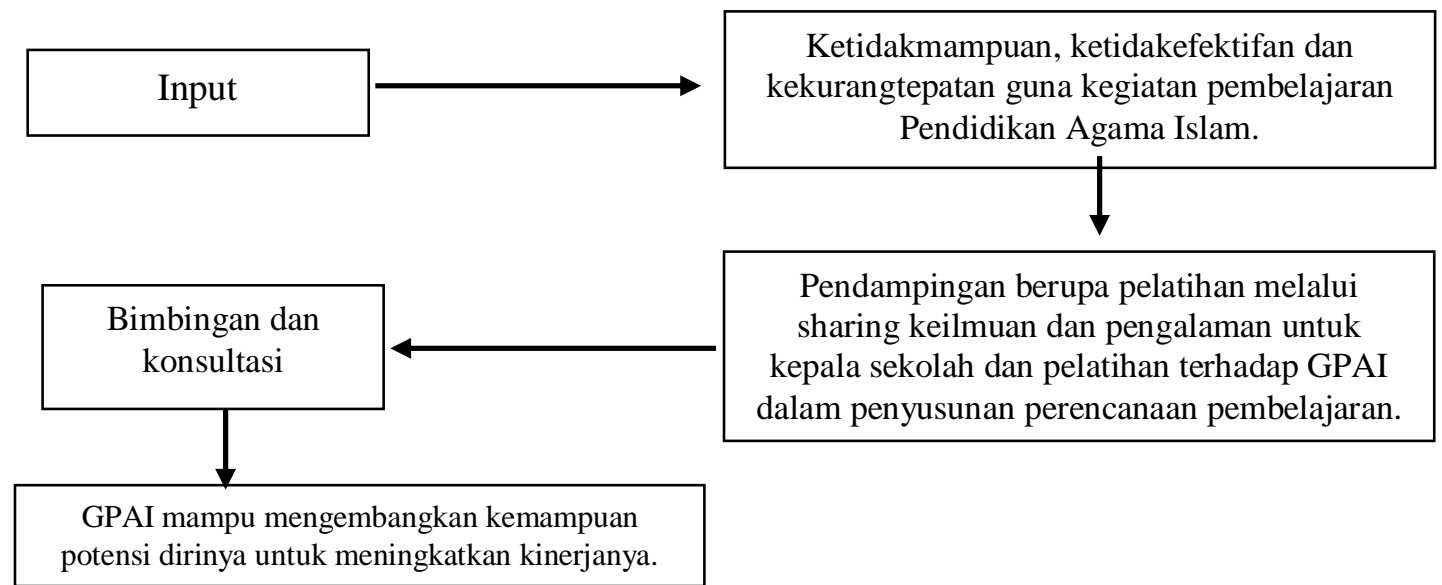

Gambar 1. Alur pemecahan problematika pembelajaran Pendidikan Agama Islam yang ada di MTs Alharanain Lappara Kec.Tombolopao Kab.Gowa

2. Khalayak Sasaran

Kegiatan pendampingan berupa pelatihan melalui sharing keilmuan dan pengalaman dengan guru Dan pelatihan terhadap guru-guru dalam satu kegiatan penyusunan perencanaan pembelajaran ini diperuntukkan bagi GPAI yang ada di MTs Alharanain Lappara Kec.Tombolopao Kab.Gowa.

3. Metode Kegiatan

Kegiatan ini secara umum berbentuk pendampingan berupa pelatihan penyusunan perencanaan pembelajaran menggunakan beberapa kegiatan, antara lain:

a. Tutorial

Kegiatan ini dilakukan untuk memberikan pelatihan kepada GPAI dalam satu kegiatan penyusunan perencanaan pembelajaran. Kegiatan ini difokuskan pada pengembangan kemampuan GPAI dalam proses pembelajaran.

b. Eksperiental Learning

Kegiatan ini dilakukan dengan memberikan pengalaman langsung bagi GPAI yang terkait kegiatan penyusunan perencanaan pembelajaran. Kegiatan ini hanya berupa sharing pengalaman antara GPAI dengan pendamping atau mitra pendamping yang memiliki kompetensi di bidang perencanaan pembelajaran.

Adapun gambaran metode pengabdian sebagaimana berikut:

\begin{tabular}{|c|c|c|c|}
\hline Assesment & Planning & Implementati & Evaluation \\
\hline $\begin{array}{l}\text { melakukan } \\
\text { FGD dengan } \\
\text { GPAI }\end{array}$ & $\begin{array}{l}\text { Merancang } \\
\text { kegiatan } \\
\text { pelatihan }\end{array}$ & $\begin{array}{c}\text { pelaksanaan } \\
\text { kegiatan } \\
\text { pelatihan }\end{array}$ & $\begin{array}{l}\text { Monitoring dan } \\
\text { juga } \\
\text { pendampingan }\end{array}$ \\
\hline
\end{tabular}

Gambar 2. Metode Pengabdian Masyarakat

\section{Rancangan Evaluasi}

Evaluasi dilakukan dalam bentuk monitoring dan pendampingan berupa pelatihan melalui sharing keilmuan dan pengalaman dengan GPAI. Sedangkan untuk guru-guru lain di MTs 
Alharanain Lappara Kec.Tombolopao Kab.Gowa dilakukan pelatihan dalam satu kegiatan penyusunan perangkat pembelajaran yang dilakukan secara terus menerus terutama perencanaan pembelajaran. Evaluasi ini dilakukan untuk mencapai tingkat kesempurnaan dalam kegiatan penyusunan perencanaan pembelajaran di MTs Alharanain Lappara Kec.Tombolopao Kab.Gowa

5. Rencana dan Jadwal Kegiatan

Kegiatan ini dilakukan selama enam bulan yaitu dari bulan Juni 2020 sampai Nopember 2020 dengan jadwal kegiatan sebagaimana berikut:

\begin{tabular}{|l|l|l|l|l|l|l|c|}
\hline \multirow{2}{*}{ No. Kegiatan } & \multicolumn{5}{c|}{ Bulan } \\
\cline { 3 - 8 } & & $\mathbf{6}$ & $\mathbf{7}$ & $\mathbf{8}$ & $\mathbf{9}$ & $\mathbf{1 0}$ & $\mathbf{1 1}$ \\
\hline 1. & Persiapan kegiatan & $\mathrm{X}$ & & & & & \\
\hline 2. & Pelaksanaan kegiatan & & $\mathrm{X}$ & $\mathrm{X}$ & & & \\
\hline 3. & Penyusunan laporan kegiatan & & & & $\mathrm{X}$ & & \\
\hline 4. & Penyusunan draft laporan & & & & & $\mathrm{X}$ & \\
\hline 5. & Penyusunan laporan akhir & & & & & & $\mathrm{X}$ \\
\hline
\end{tabular}

\section{HASIL DAN PEMBAHASAN}

Hal yang perlu ada dalam konteks MTs Alharanain Lappara Kec.Tombolopao Kab.Gowa ini adalah kegiatan yang ditujukan untuk memberikan pendampingan berupa pelatihan melalui sharing keilmuan dan pengalaman dengan guru berbagai bidang studi atau mata pelajaran. Dengan kegiatan ini diharapkan dapat membekali tenaga pendidik menguasai metodologi pembelajaran dengan baik. Kegiatan pendampingan diteruskan dengan program pelatihan terhadap guru berbagai bidang studi ini dalam satu kegiatan yang berupa penyusunan perangkat pembelajaran. Melalui dua kegiatan ini diharapkan mampu meningkatkan dan mengembangkan kemampuan guru dalam metodologi proses belajar mengajar. Artinya, perlu ada workshop atau pelatihan khusus dari tenaga ahli dalam bidang metodologi pembelajaran yang bisa meningkatkan dan mengembangkan kembali kompetensi guru-guru MTs Alharanain Lappara Kec.Tombolopao Kab.Gowa

Realisasi persiapan kegiatan pengabdian dilaksanakan dengan melakukan persiapan-persiapan, antara lain: 1). Melakukan studi pustaka tentang berbagai cara pelatihan metodologi pembelajaran guru; 2). Melakukan persiapan alat dan bahan untuk pelatihan metodologi pembelajaran guru; 3). Menentukan waktu pelaksanaan dan lamanya kegiatan pengabdian bersama-sama tim pelaksana terutama dengan pembicara; dan 4). Menentukan dan mempersiapkan materi yang akan disampaikan dalam kegiatan pengabdian tersebut. Persiapan-persiapan ini sangat menentukan pengambilan keputusan dan penentuan ahli yang ditunjuk untuk menjadi pembicara pada kegiatan tersebut. Karenanya, langkah-langkah ini membuka pintu konkritisasi kegiatan pelatihan kegiatan metodologi pembelajaran.

Akhirnya, pelaksanaan kegiatan pengabdian berlangsung dengan dihadiri 10 orang peserta guru MTs Alharanain Lappara Kec.Tombolopao Kab.Gowa. Kegiatan berupa penyampaian materi dan praktek langsung cara mengajar, sehingga kegiatan ini fokus pada pembahasan metodologi pembelajaran. Hasilnya, kegiatan pengabdian ini memiliki relevansi dengan kebutuhan kegiatan pelatihan metodologi pembelajaran guru MTs Alharanain Lappara Kec.Tombolopao Kab.Gowa Berdasarakan hasil survey 
sebelum pelaksanaan, para guru PAI yang mempunyai skill dan wawasan keilmuan mengajar atau metodologi pembelajaran perlu ditingkatkan lagi agar lebih profesional. Sehingga diharapkan para guru PAI dapat melaksanakan pembelajaran dengan baik dan profesional.

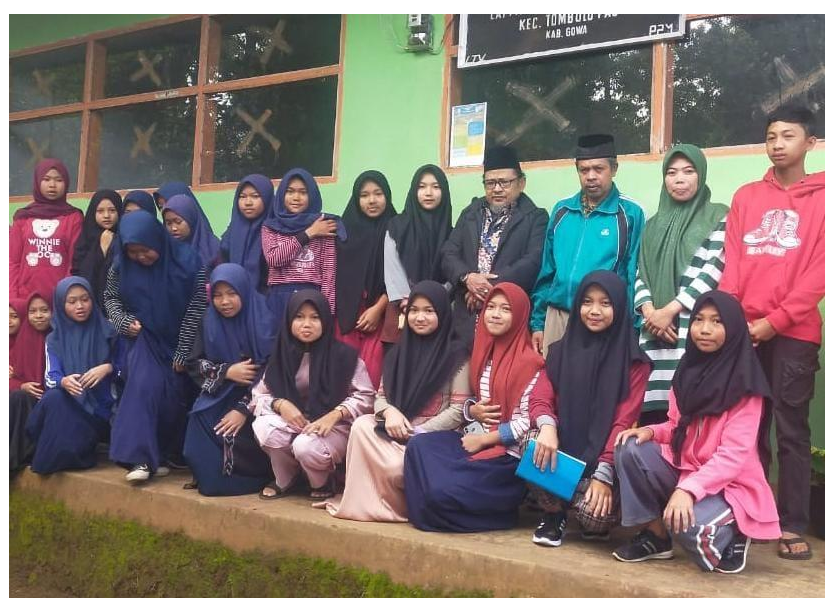

Gambar 3. Peserta Pendampingan Kegiatan Pembelajaran

Pendidikan Agama Islam di MTs Alharanain Lappara Kec.Tombolopao Kab.Gowa (Abd. Rahim Razaq \& Umiarso, n.d.)

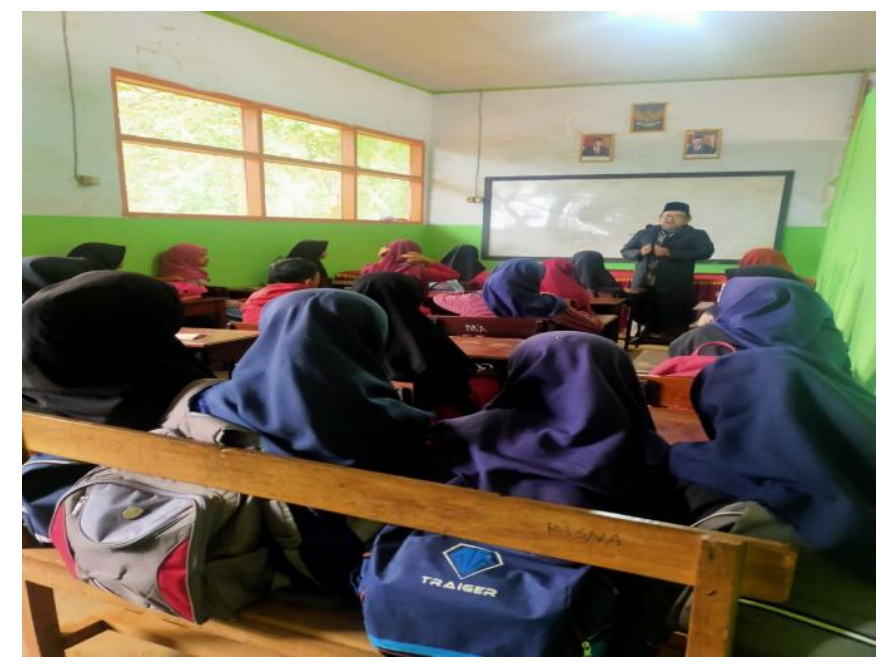

Gambar 4. pembahasan metodologi pembelajaran oleh pemateri (Abd. Rahim Razaq \& Umiarso, n.d.)

Dalam sesi pelatihan metodologi pembelajaran, guru diharapkan mampu memilih model pembelajaran yang sesuai dengan materi yang diajarkan. Di mana dalam pemilihan metodologi pembelajaran meliputi pendekatan suatu model pembelajaran yang luas dan menyeluruh. Misalnya pada model pembelajaran berdasarkan masalah, kelompok-kelompok kecil peserta didik bekerja sama memecahkan suatu masalah yang telah disepakati oleh peserta didik dan guru(Sahrudin, 2016, p. 4), ketika guru sedang menerapkan model pembelajaran tersebut, seringkali peserta didik menggunakan bermacam-macam keterampilan, prosedur pemecahan masalah dan berpikir kritis. Model pembelajaran berdasarkan masalah dilandasi oleh teori belajar konstruktivis (Shoimin, 2014). Pada model ini pembelajaran dimulai dengan menyajikan permasalahan nyata yang penyelesaiannya membutuhkan kerjasama diantara seluruh peserta didik. Dalam model pembelajaran ini guru 
memandu peserta didik menguraikan rencana pemecahan masalah menjadi tahap-tahap kegiatan; guru memberi contoh mengenai penggunaan keterampilan dan strategi yang dibutuhkan supaya tugas-tugas tersebut dapat diselesaikan. Guru menciptakan suasana kelas yang fleksibel dan berorientasi pada upaya penyelidikan oleh peserta didik.

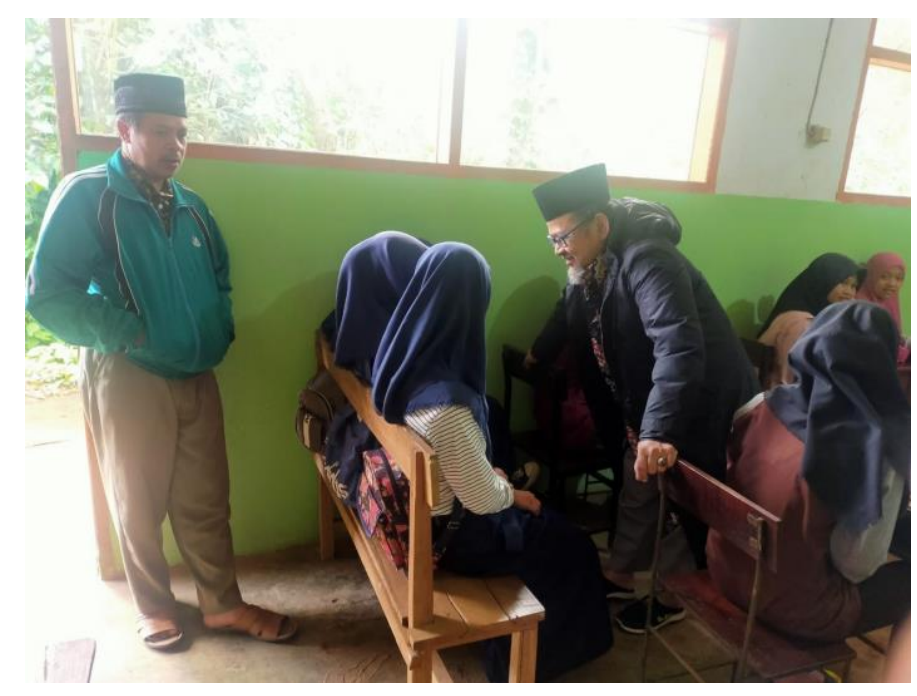

Gambar 5. Peserta melakukan konsultasi dengan pemateri (Abd. Rahim Razaq \& Umiarso, n.d.)

Berdasarkan kegiatan tersebut hasil dari pelatihan metodologi pembelajaran ini, antara lain: 1). Hasil pelatihan berdasarkan wawancara, tanya jawab dan pengamatan langsung selama kegiatan berlangsung, kegiatan pengabdian pada masyarakat ini memberikan hasil sebagai berikut: a. Meningkatnya pengetahuan dan wawasan guru MTs Alharanain Lappara Kec.Tombolopao Kab.Gowa tentang metode pembelajaran; b. Meningkatnya keterampilan guru MTs Alharanain Lappara Kec.Tombolopao Kab.Gowa dalam penyelenggaraan pembelajaran sehingga dimungkinkan guru PAI dapat mempraktekkan ilmu yang diperoleh kepada peserta didik di tempat mereka mengajar yaitu MTs Alharanain Lappara Kec.Tombolopao Kab.Gowa. Dan hasil yang 2). Faktor pendukung dan faktor penghambat, yaitu: beberapa faktor yang mendukung terlaksananya kegiatan pengabdian di MTs Alharanain Lappara Kec.Tombolopao Kab.Gowa ini adalah besarnya minat dan antusiasme peserta selama kegiatan, sehingga kegiatan berlangsung dengan lancar dan efektif. Sedangkan faktor penghambatnya adalah keterbatasan waktu pelatihan.

\section{SIMPULAN}

Berdasarkan pada paparan dari pembahasan tersebut dapat disimpulkan bahwa pengabdian ini melalui pelatihan metodologi pembelajaran di MTs Alharanain Lappara Kec.Tombolopao Kab.Gowa Kondisi ini juga berdampak pada peningkatan performa guru yang dibuktikan melalui penilaian berkasberkas pembelajaran yang digunakan mereka. Hal tersebut dapat dikatakan bahwa tujuan pengdian ini tercapai, dengan merujuk dari indikator-indikator pencapaiaan yang meliputi keberhasilan dalam pola pendampingan yang memfokuskan kepada kegiatan eksperiental learning. Dimana melalui pola kegiatan ini guru mendapatkan pengalaman dan ketrampilan secara langsung, sedangkan melihat dari 
dampak yang ditimbulkan dari upaya peningkatan keterampilan guru yang berupa pendampingan tersebut, maka kepala sekolah perlu setiap saat secara berkala mengadakan upaya yang sama yaitu pelatihan metodologi pembelajaran di MTs Alharanain Lappara Kec.Tombolopao Kab.Gowa Sedangkan tenaga pendidik untuk senantiasa melakukan pengembangan dan peningkatan kompetensinya dengan tidak bergantung kepada upaya sekolah dalam mengadakan pelatihan metodologi pembelajaran.

\section{UCAPAN TERIMA KASIH}

Terimakasih kami sampaikan kepada Allah SWT. atas berkat Rahmatnya pengabdian ini dapat berjalan dengan lancar. Terimakasih kami sampaikan kepada Kepala Sekolah MTs Alharanain Lappara Kec.Tombolopao Kab.Gowa yang telah memberikan kesempatan kepada kami untuk melaksanakan kegiatan pengabdian ini sehingga dapat berjalan dengan lancar.

\section{DAFTAR PUSTAKA}

Abd. Rahim Razaq \& Umiarso. (n.d.). Dokumen Peneliti. Cilacap.

Hamalik, O. (2009). Pendidikan Guru: Berdasarkan Pendekatan Kompetensi. Jakarta: Bumi Aksara. Muhaimin. (2005). Pengembangan Kurikulum Pendidikan Agama Islam Di Sekolah, Madrasah Dan Perguruan Tinggi. Jakarta: Rajawali Pers.

Muhaimin. (2006). Nuansa Baru Pendidikan Islam: Mengurai Benang Kusut Dunia Pendidikan. Jakarta: Rajawali Pers.

Mulyasa, E. (2004). Pendidikan Agama Islam Berbasis Kompetensi: Konsep dan Implementasi Kurikulum 2004. Bandung: Remaja Rosdakarya.

Sahrudin, A. (2016). Implementasi Model Pembelajaran Means- Ends Analysis Untuk Meningkatkan Kemampuan Pemecahan Masalah Matematika Mahasiswa. Jurnal Pendidikan Unsika, 4(1), 17 25 .

Shoimin, A. (2014). 68 Model Pembelajaran Inovatif dalam Kurikulum 2013, (. Yogyakarta: Ar- Ruzz Media.

Sutisna, U., Elkarimah, M. F., \& Asma, F. R. (2020). Pengembangan kompetensi profesional guru PAI melalui pemanfaatan teknologi informasi. ABSYARA: Jurnal Pengabdian Pada Masyarakat, 1(2), 9-14. https://doi.org/10.29408/ab.v1i2.2629

Uno, H. B. (2008). Profesi Kependidikan: Problema, Solusi, Dan Reformasi Pendidikan di Indonesia. Jakarta: Bumi Aksara.

Usman, M. U. (2005). Menjadi Guru Profesional. Bandung: Remaja Rosdakarya. 